\title{
LEGAL PROTECTION OF SAME-SEX RELATIONSHIPS IN AUSTRALIA *
}

\author{
The Hon. Justice \\ Michael Kirby A.C. C.M.G. Hon. LL.D. **
}

\section{LAW TURNED ON ITS HEAD}

In matters of personal morality, Lord Denning reflected the times in which he grew up. ${ }^{1}$ He was a child of the post-Victorian era. He took seriously the moral instruction of the Anglican Church within the Christian religion. Although enlightened on many topics affecting society and generally a reformer when it came to law, ${ }^{2}$ Lord Denning was not very enlightened on the issues affecting human sexuality. He cannot be blamed for this. He was a product of his era, his Church, his education and his profession.

In more recent times, the law, and even the churches ${ }^{3}$ and other religious institutions have begun to re-examine the previous assumptions concerning

" Based on a lecture given to the School of Law, University of Buckingham, $3^{\text {rd }}$ March, 2000 in association with the conferral upon the author of the Honorary Degree of Doctor of Laws. Some parts of this essay were previously published in (1999) 19 Australian Bar Review 4.

** Justice of the High Court of Australia. One-time President of the International Commission of Jurists and Laureate of the UNESCO Prize for Human Rights Education.

1 For a reflection on Lord Denning's views on moral questions, see A.Phang, "The Natural Law Foundations of Lord Denning's Thought at Work" [1999] Denning Law Journal 159. For an earlier commentary on his application of Christian principles of morality to legal decisions, see M.D.Kirby, "Lord Denning: An Antipodean Appreciation" [1986] Denning Law Journal 103 at p. 110 commenting on Ward v. Bradford Corporation (1972) 70 L.G.R. 27.

2 For essays on Lord Denning's contribution to reform of the law of obligations, of public law, of family law and of other legal disciplines see the essays collected in [1999] Denning Law Journal 1-186.

${ }^{3}$ For an enlightened view from a Christian viewpoint see A.A.Brash, "Address to Ecumenical Centre, Geneva, Switzerland, 1994 - The Churches and their Gay and Lesbian Members" in A.A.Brash, Footsteps in the Sand, (Caxton, N.Z., 1999) at p.73. 
homosexual orientation and the sexual acts to which such orientation normally gives rise. In international courts and tribunals, ${ }^{4}$ in the courts of the United States, ${ }^{5}$ England ${ }^{6}$ and Canada ${ }^{7}$ decisions have been delivered which begin to redress the discrimination previously evident in the law. Because it was the criminalisation of homosexual conduct by the laws of England that was copied in the criminal laws of the British Empire (even in places where the law had previously made no distinctions on the basis of sexuality) it was appropriate that leadership torwards reform should eventually have come from the United Kingdom. The Wolfenden Report ${ }^{8}$ and the legislative reform that followed ${ }^{9}$ became models which influenced the repeal of the statutory provisions which rendered it a crime for individuals to engage in homosexual conduct.

Commonly, such provisions rendered such conduct a crime in the case of males, even where the conduct occurred in private and involved only adults. Consent was no defence.

The Wolfenden reforms in England, and the like reforms which were adopted elsewhere, stimulated reflections upon existing discriminations in the law

${ }^{4}$ See e.g. Dudgeon v. United Kingdom (1981) 4 E.H.R.R. 149; Norris v. Republic of Ireland (1988) 13 E.H.R.R. 186; Modinos v. Cyprus (1993) 16 E.H.R.R. 485; Lustig-Prean and Beckett v. United Kingdom (2000) 29 E.H.R.R. 493.

${ }^{5}$ There are many contemporary decisions of courts in the United States. The California Court of Appeal in People v. Garcia 2000 Daily Appellate Report 1235 ( $4^{\text {th }}$ Dist. $)$ held. that a peremptory challenge to two homosexual jurors violated the accused's constitutional rights. The Vermont Supreme Court has held that couples in same-sex relationships must receive the same common civil benefits as flow from marriage under Vermont law. See Baker v. State of Vermont 744 A 2d 864 (1999).

${ }^{6}$ Fitzpatrick v. Sterling Housing Association Ltd. [1998] Ch. 304; [1999] 3 W.L.R. 1113; [1999] 4 All E.R. 705 cited in The Grain Pool of W.A. v. The Commonwealth [2000] H.C.A. 14 at 127. Cf. Re Wakim; Ex parte McNally (1999) 73 A.L.J.R. 839 at 850 where McHugh J. suggested that the "marriage" power afforded to the Federal Parliament under s.51(xxi) of the Australian Constitution would arguably today or in the near future mean a voluntary union between two people and thus extend to empower federal legislation on same-sex marriages. 7 Egan v. Canada [1995] 2 S.C.R. 513; $M$ v. $H$ [1999] S.C.R. 23. See generally R. Wintemute, "Discrimination Against Same-Sex Couples: Sections 15(1) and 1 of the Charter, Egan v. Canada" (1995) 74 Canadian Bar Review 682; R. Wintemute, "Sexual Orientation Discrimination as Sex Discrimination: Same-Sex Couples and the Charter in Mossett, Egan and Layland" (1994) 39 McGill Law Journal 427.

${ }^{8}$ Homosexual Offences and Prostitution, Cmnd. 247, (H.M.S.O., 1957).

9 In England, the Sexual Offences Act 1967 (U.K.). 


\section{SAME-SEX RELATIONSHIPS}

affecting fellow citizens who happened to be homosexual. Once the unquestioning adherence to the moral precepts reflected in the previous law came under question, the range and extent of the discrimination that existed came to be realised. Once this happened, the need to remove discriminatory provisions in the law, which could not be justified by sound reasons, came to be accepted by legislators, administrators and courts alike. This process of acceptance and law reform is ongoing.

In my lifetime, I have watched these changes. I have done so with more than academic interest. For me, they were not simply an extension of the earlier struggle for the removal of discrimination against women and against people whose skin colour was different from my own. This was a discrimination that affected me personally. From earliest youth, if one were homosexual (as I was) one was expected to be thoroughly ashamed of that fact and to observe a code of total secrecy about it. Many citizens, and not a few lawyers, still do so. But thanks to a growing moral enlightenment, an appreciation of the injustice of stigmatising people for an element of their nature that they do not choose and cannot change, increasing numbers of people (including some lawyers) are now addressing the injustice and discrimination that remains in the law on this ground. They are doing so with impatience and a desire to contribute to law reform. This is a feature of the age we now live in, at least in those Western societies which have felt the impact of scientific research about human sexuality ${ }^{10}$ and the influence of legal developments that draw upon the international jurisprudence of human rights. "Such changes, it may be expected, will come in time to affect all societies in the world as ignorance, mythology, prejudice and religious bigotry are replaced by knowledge, human rights and social and individual enlightenment.

In short, the law is being turned on its head. No longer the oppressor of homosexual citizens, law is now is being invoked to protect their rights and to secure their true equality. Changes are happening in many countries. The

${ }^{10}$ For changes in the approaches of psychiatry and psychology to homosexuality, and the deletion of homosexuality from national and international manuals of psychiatric disorders, see M.King and A.Bartlett, "British Psychiatry and Homosexuality" (1999) 175 British Journal of Psychiatry 106 and M.D.Kirby, "Remaining Sceptical: Lessons from Psychiatry's Mistreatment of Homosexual Patients" (2000) 44 Quadrant 48.

11 Toonen v. Australia (1994) 1:3 Int. Human Rights Reports 97. See also Croome v. Tasmania (1997) 191 C.L.R. 119. 


\section{THE DENNING LAW JOURNAL}

purpose of this note is to outline some of the changes that have recently occurred in Australia.

\section{CHANGES IN STATE LEGISLATION}

It is beyond the scope of this paper to review all of the legislation in each of the eight sub-national Australian jurisdictions that touch all of the legal rights of persons in same-sex relationships. I will therefore concentrate on the State of New South Wales, which is the most populous State in Australia. As in most Australian jurisdictions which inherit statutes going back to colonial times, a large number of enactments of the New South Wales Parliament (and some of them not so old) reflect prejudice and discrimination against homosexual citizens. This has been repeatedly called to notice by the State's AntiDiscrimination Board. ${ }^{12}$

The examples of discriminatory laws are many. They are found in every corner of the law - even unexpected corners. Thus, the Stamp Duties Act 1920 (N.S.W.) provides that, if a share of a jointly owned property is sold by one party in a heterosexual relationship following the end of that relationship and if so ordered by a court, the remaining partner may be exempted from paying stamp duty. There is no such entitlement to exemption for a same-sex partner. Similarly, the Superannuation Act 1916 (N.S.W.) contains a definition of "spouse" in relation to a death benefit which has the consequence that, where a contributor to a superannuation scheme or pensioner who dies without leaving a legally recognised "spouse" (or, in some cases, children) that person will receive only a refund of contributions without interest. This involves less favourable treatment for partners of the same sex and some others who are less likely to have a lawful "spouse" or child.

The Adoption of Children Act 1965 (N.S.W.) provides that a court may make an adoption order in favour of a married couple or, in certain circumstances, of a man and a women in a de facto relationship. Such an order cannot be made in favour of persons in a same-sex relationship, whatever its duration and whatever the exceptional circumstances of the case. I know of several cases where couples in same-sex relationships have successfully reared children of one of the partners in a previous marriage. Adoption is impossible. In each case the

12 New South Wales Anti-Discrimination Board, Newsletter, Equal Time, (February, 1999). 
children love their "parents" and have grown up robustly heterosexual; but tolerant. The Evidence Act 1995 (N.S.W.) contains legal privileges in respect of opposite-sex couples which are not extended to same-sex partners. ${ }^{13}$

The New South Wales Anti-Discrimination Board has submitted to the State Parliament and Government that the legislation of the State needs to be changed to afford wider recognition to relationships involving same-sex partners and persons in non-traditional and/or extended family relationships. Because growing numbers of persons in a variety of human relationships fall outside the protection of the present law, reform of the law is needed. But reform is sometimes slow in coming.

The New South Wales Equal Opportunity Tribunal established by the AntiDiscrimination Act 1977 (N.S.W.) is empowered to hear complaints in certain circumstances where a person claims to have suffered discrimination on the ground of homosexuality. Such complaints are now regularly taken to the Tribunal. In 1995 the Tribunal found that a health fund which had refused to allow the complainants a "family" or "concessional" rate was guilty of unlawful discrimination. The complainants were two males bringing up the son of one of them. They had joint bank accounts, joint ownership of a motor vehicle and a joint mortgage. Although the couple did not fit within the "spouse" relationship under the rules of the fund, they did come within the "family" relationships as defined. They were entitled to the concessional rate. An appeal by the fund to the Supreme Court of the State failed. ${ }^{14}$

As a background to what now follows, it is appropriate to say that such studies as have been conducted in Australia to sample the opinion of same-sex partners seems to indicate that the majority surveyed ( 80 per cent) do not consider that marriage or marriage equivalence is necessary in their cases. ${ }^{15}$ Many homosexual people regard marriage as such to be irrelevant to their relationship and look on it as a heterosexual legal construct with defects which they do not necessarily wish to copy. However, they want the discrimination removed and equivalent provision of legal protections against discrimination in respect of

13 Evidence Act 1995 (N.S.W.) s. 18; Evidence Act 1995 (Cth.) s. 18

14 NIB Funds Limited v. Hope $15^{\text {th }}$ November, 1996, Supreme Court (N.S.W.), unreported.

Cf. Fitzpatrick v. Sterling Housing Association supra n.6.

15 S.Sarantakos, "Legal recognition of same-sex relationships" (1998) 23 Alternative Law Journal 222; S.Sarantakos, "Same-Sex Marriage: Which Way to Go?" (1994) 24 Alternative Law Journal 79 


\section{THE DENNING LAW JOURNAL}

civil rights and benefits that attach in law to the relationship of marriage. At least in the State of New South Wales the legislators are at last responding to this latter demand.

In 1998 the Same-Sex Relationships (Compassionate Circumstances) Bill 1998 (N.S.W.) was introduced into the New South Wales Parliament to meet what were described as "urgent areas of need which relate to wills, family provision and hospital access" for same-sex partners. ${ }^{16}$ The purpose of the Bill, a Private Member's measure, was to pick up on a commitment given by the State Premier to the President of the A.I.D.S. Council of New South Wales prior to the election in which his party was elected to Government in 1995. That commitment was:
"Labor is committed to reform of legislation around same-sex relationships so that same-sex partners have the same rights and responsibilities as heterosexual de factos when their partner is hospitalised or incapacitated. We will also ensure that same-sex partners are not discriminated against in the operation of will and probate and family provisions."

The 1998 measure was not enacted. The Government cancelled the allocation of time to Private Members for the remainder of the parliamentary session. Several other Private Member's Bills on related topics also lapsed when the New South Wales Parliament was dissolved for a State election held in March, 1999.

The new State Parliament which convened after the re-election of the Government moved quickly to enact the Property (Relationships) Legislation Amendment Act 1999 (N.S.W.). The Bill for that Act was introduced into the Legislative Council by the State Attorney-General (Mr. J.W.Shaw Q.C.). It was passed by that Chamber by 37 votes to 3 . In the Legislative Assembly, it was passed without division. The debates were notable for the enlightened views expressed by members of both Houses and both sides of politics. Mr. Shaw

${ }_{17}$ C.Moore M.P., Media Release, (N.S.W.), $20^{\text {th }}$ October, 1998.

17 Letter by the Hon. R. Carr M.P. to the President, A.I.D.S. Council of N.S.W., $22^{\text {nd }}$ February, 1995. See Statement by Ms. Clover Moore M.P. to the Legislative Assembly of New South Wales in New South Wales Parliamentary Debates (Legislative Assembly) $22^{\text {nd }}$ October, 1998 at 59. 


\section{SAME-SEX RELATIONSHIPS}

described the legislation as "historic," which for Australia it certainly is. $\mathrm{He}$ went on:

"In an open and liberal society, there is no excuse for discrimination against individuals in our community based on their sexual preference. To deny couples in intimate and ongoing relationships within the gay and lesbian community the same rights as heterosexual de facto couples is clearly anomalous."

A speech by a National Party member of the Lower House, representing a country electorate and a party sometimes described as conservative (Mr. Russell Turner M.P.) was specially striking:

"Generally, they [people in same-sex relationships] have faced life, they have been through agonies and they, in a lot of instances, are probably far better adjusted than many married couples who are living in a state of acceptance by the community, the church, and the laws of this country."19

The legislation broadly assimilates same-sex partners within the De Facto Relationships Act 1984 (N.S.W.) which is renamed the Property Relationships Act - itself a sign of how common de facto relations of all kinds are in Australia today.

The thrust of the New South Wales Act is to allow for court orders adjusting property relations on the termination of a domestic relationship outside marriage. The rights affected include real and personal property rights, such as rights to succession of intestacy, taxes in relation to property transfers between partners, insurance contracts, protected estates, family provision (following inadequate testamentary provision) and a limited provision affecting State judges' pensions. Non-property rights are also conferred in relation to human

18 See New South Wales Parliamentary Debates (Legislative Council) $13^{\text {th }}$ May, 1999, at $228 ; 26^{\text {th }}$ May, 1999 , at 36.

19 See New South Wales Parliamentary Debates (Legislative Assembly), $1^{\text {st }}$ June, 1999, at 740-741. Subsequently the State Leader of the National Party was reported as predicting that there would be "no more watering down our opposition to indulgent and selfish gay rights laws" Sydney Morning Herald, $19^{\text {th }}$ June, 1999, at p. 11. 


\section{THE DENNING LAW JOURNAL}

tissue and medical treatment decisions, participation in coronial inquests, decisions about bail for arrested persons, guardianship and mental health decisions, rights in retirement villages and accident compensation.

A multitude of New South Wales statutes are amended by the 1999 Act to impose on same-sex couples the same obligations to disclose interests as would exist in the case of spouses. Areas acknowledged as still requiring attention include adoption, foster parenting and superannuation for State government employees. The New South Wales Legislative Council's Standing Committee on Social Issues (chaired by the Hon. Jan Burnswoods) has a reference from the New South Wales Parliament on relationships law reform generally. The Committee has called for submissions on the ways in which the Property Relationships Act as it now stands does not adequately address legal concerns necessary to remove residual legal discrimination against same-sex domestic partners under State law.

One matter on the list for future legislation may be the age of consent laws which, as in England, discriminate in between males (18 years) and females (16 years). Legislation on this topic has been promised. A Private Member's Bill on the subject struck in the Upper House of the Parliament of New South Wales some of the same opposition, for much the same reasons, as recently faced similar legislative proposals in the House of Lords.

Most other Australian State and Territory Governments have not yet indicated an intention to follow the lead of the New South Wales Government and Parliament. However, legislative reforms similar to the Property Relationships Act have recently been enacted by the Queensland Parliament. ${ }^{20}$ A new Government in Victoria has committed itself to examining the change. This model has been rejected in New Zealand as not going far enough. ${ }^{21}$ On a national level, the importance of the foregoing developments should not be exaggerated. Yet they are still significant and symbolic. In a Federation such as Australia, reforms enacted in one jurisdiction tend, in time, to influence developments in others. Once it was South Australia that led the way in such matters (including decriminalisation of homosexual acts and the enactment of Anti-Discrimination legislation). This time it has been New South Wales and later Queensland.

20 Property Law Amendment Act 1999 (Qld.).

21 Dugdale, "Same-Sex Relationships" (February, 2000) New Zealand Low Journal 3 
Even before the foregoing general reforms were adopted legislation was enacted by the New South Wales Parliament which provided an interesting model to afford protection to people in same-sex relationships. Thus, the Workers' Compensation Legislation Amendment (Dust Diseases and Other Matters) Act 1998 (N.S.W.) contained, in Schedule 6, a number of amendments to the Workers' Compensation (Dust Diseases) Act 1942 (N.S.W.). Amongst those changes was an amendment to section 3 of the Act. It inserted a new definition of "de facto relationship" in section 3(1) of the Principal Act. The redefinition is broad enough to encompass same-sex relationships:

"De facto relationship means the relationship between two unrelated adult persons:

(a) Who have a mutual commitment to a shared life, and

(b) Whose relationship is genuine and continuing, and

(c) Who live together, and

who are not married to one another."

Further amendments, which were enacted by the New South Wales Parliament, add a new subsection to section 3 of the Principal Act:

"For the purposes of determining whether two persons are in a de facto relationship for the purposes of this Act, all the circumstances of the relationship are to be taken into account, including (but without being limited to) matters prescribed by the regulations for the purposes of this subsection."

This is another legislative provision which allows for definitional flexibility as social considerations develop and change. Much work remains to be done. But significant reforms have been accepted in Australia's most populous State. A model has been provided for the rest.

\section{CHANGES IN FEDERAL LEGISLATION}

The Australian Constitution, approaching its centenary, is one of the four oldest documents of its kind still in operation in the world. When adopted it did not 


\section{THE DENNING LAW JOURNAL}

contain a general Bill of Rights such as became common in the independence constitutions of other countries of the Commonwealth of Nations. There is therefore no precise equivalent to the Bill of Rights in the United States Constitution or the Charter later adopted to supplement the British North America Act (now renamed the Canadian Constitution) to stimulate and facilitate challenges to discriminatory provisions in federal law. Generally speaking, in such matters Australians must rely on the Federal Parliament and Government to secure changes. Only rarely can the aid of the courts be involved.

Under the Australian Constitution, one matter upon which the Federal Parliament enjoys legislative power is "immigration and emigration."22 Since 1984, in part because of lobbying by the Gay and Lesbian Immigration Task Force (G.L.I.T.F.), changes have been introduced into Australian migration law and practice which have expanded the rights of entry into Australia of persons in same-sex relationships.

The main breakthrough occurred in 1985. Upon the instructions of the then Minister (the Hon. Chris Hurford), regulations and practices were adopted which removed much discrimination and provided for the consideration of applications for migration to Australia largely (but not entirely) on an equal footing so far as same-sex partners are concerned.

Entry into Australia of non-residents is regulated by the Migration Act 1958 (Cth.) and the regulations made under that Act. The regulations now provide for visa subclasses to permit the entry of people in "inter-dependent" relationships. This is the adjectival phrase which has been adopted to describe same-sex partners. The relevant Australian visa classes are 310 and 301. They permit migration to Australia of a person sponsored by his or her partner. Comparable visas to allow change of status of persons already within Australia are visa classes 826 and $814 .^{23}$ The two categories mirror, in turn, those applying to persons seeking entry to Australia on the basis of a de facto heterosexual relationship.

\footnotetext{
22 Australian Constitution, s.51(xxvii). The Federal Parliament enjoys legislative powers with respect to naturalisation and aliens (s.51(xix)) and external affairs (s.51(xxix))

23 D.Bitel, "Recognition of Same-Sex Relationships in Australian Immigration Law" unpublished paper to the International Bar Association Conference, Vancouver, September, 1998 at p.3. See esp. Migration Regulations, reg. 1.09A ("Interdependent relationships")
} 
The annual migration programme for Australia contains an allocated number of places available to persons in the "inter-dependent" categories. By comparison to the total size of Australia's migration programme, the numbers are very small. For the financial year 1996-97, 400 places were reserved for "interdependency visas." Nevertheless the category now exists in Australian law. I know fine new citizens of Australia, some in the legal profession, who have taken advantage of it.

Discrimination remains in Australian migration law and practice. Thus, in "interdependency relationships" involving homosexual de facto partners, the partners must be able to prove a twelve months committed relationship before being eligible to proceed with the application. In the case of heterosexual relationships, this precondition can be overcome, quite simply and quickly, by marriage, an event substantially within the control of the persons themselves. A similar short-cut is not available to same-sex couples. In some countries which still criminalise, prosecute or stigmatise persons who establish a same-sex household, proof of twelve months cohabitation, especially with a foreigner, may be difficult or even impossible. Provision is made for waiver of this requirement in compelling circumstances.

Notwithstanding the continuing defects of current law, it is clear that Australian migration regulations are comparatively enlightened on this subject. As yet, only a handful of countries (the Netherlands, the Scandinavian nations, Australia, New Zealand and Canada) recognise same-sex relationships in any way for immigration purposes. Not until October, 1997 did the United Kingdom do so. Then the Minister announced a "concession" whereby, at least in some cases, unmarried relationships would be recognised for purposes of immigration to the United Kingdom, including same-sex partners, a category formerly rejected. ${ }^{24}$

In the field of refugee law, Australia is a party to the Refugees Convention which is incorporated into Australian domestic law. ${ }^{25}$ One of the categories entitled to refugee status is that of a person one who "owing to a well-founded fear of being persecuted for reasons of ... membership of a particular social

24 R.Wintemute, Sexual Orientation and Human Rights, (Clarendon Press, Oxford, 1995) at pp.103-105; W. Gryk, "The Recognition of Unmarried Relationships Under British

Immigration Law - An Evolving Process?" unpublished paper to the International Bar Association Conference, Vancouver, $16^{\text {th }}$ September, 1998, at p.2.

25 Migration Act 1958 (Cth.), s.4(1). 


\section{THE DENNING LAW JOURNAL}

group ... is outside the country of his nationality and is unable or, owing to such fear, is unwilling to avail himself of the protection of that country." The possibility that in some countries homosexuals and others in same-sex relationships would be so categorised has been recognised in a number of decisions in Australia and the United Kingdom. ${ }^{26}$ In Australia, for at least five years, both the Department of Immigration at the primary level and the Refugee Review Tribunal, have accorded refugee status to both male and female homosexuals who could establish a well founded fear of persecution in their country of nationality. ${ }^{27}$ Various problems arise in such a case because of views sometimes taken in the Tribunal concerning the need for applicants to prove their sexual orientation and because of a paucity of information about the persecution of homosexuals in some countries. Australia has developed admirable policies for the group "women at risk." There may be a need for similar supportive programmes for homosexual refugees and also for their same-sex partners. ${ }^{28}$ Many of them are at serious risk in their countries of origin or temporary residence.

Superannuation in Australia is now largely regulated by federal laws. ${ }^{29}$ The Senate Select Committee on Superannuation of the Australian Parliament delivered a report relevant to this subject in September, $1997 .{ }^{30}$ The Committee put forward "as a general proposition" a proposal earlier made to it in the context of a review of superannuation, that persons without defined dependants (such as widow, widower or eligible children) should have an entitlement under federal law to nominate a beneficiary so that they did not lose entirely the benefit of entitlements which would otherwise accrue to them were they in a currently defined relationship. The Committee recognised that the present

${ }^{26}$ Cf. Applicant A v. Minister for Immigration and Multicultural Affairs (1997) 190 C.L.R 225 at 304 (fn. 296). See also R v. Immigration Appeal tribunal, ex parte Shah [1999] 2 W.L.R. 1015 at 1044 per Lord Millett ["... [g]iven the hostility encountered by all homosexuals in such a society and the obvious problems the applicant would have in satisfying his tormenters of his own sexual abstinence, I doubt that the difficulty [of establishing that a fear of persecution was well founded] would be a real one."]

27 Bitel, supra n.23 at pp. 4-5

28 Cf. ibid at p.5.

29 Attorney-General v. Brechtler (1999) 73 A.L.J.R. 981 at 993-996.

30 Australian Parliament, Senate Select Committee on Superannuation, the Parliamentary

Contributory Superannuation Scheme and the Judges' Pensions Scheme, $25^{\text {th }}$ Report, (Canberra, September, 1997). 


\section{SAME-SEX RELATIONSHIPS}

provisions involved a "discrimination against those ... not in a recognised relationship." 31 The Committee held back from making a recommendation that provision should be made for the "nomination of a dependant" because of reconsideration of the current structure of the scheme established by the Act. ${ }^{32}$ However, as in the case of the Parliamentary Scheme applicable to federal politicians, the Committee recommended ${ }^{33}$ that the rules under which the benefits were paid "should be reviewed to ensure that they are in accordance with community standards."

In 1998 a Private Member's Bill ${ }^{34}$ was introduced into the House of Representatives by an Opposition member designed to remove discrimination against same-sex couples in relation to superannuation. Earlier, a larger measure was introduced into the Australian Senate, ${ }^{35}$ also by a non-Government Senator. The latter was referred to the Senate Legal and Constitutional References Committee. In December, 1997, that Committee tabled a report recommending that couples or partners should be protected by superannuation entitlements regardless of their sexuality or gender. Neither of the foregoing Bills has yet attracted the support of the Australian Government. In March, 2000 a Private Member's Bill identical to the one that had stalled in the House of Representatives was introduced into the Australian Senate in the hope of advancing consideration of its proposals by the Parliament. It remains under consideration at the time of writing.

Discrimination in the field of superannuation and like benefits has become more noticeable in Australia as other federal legislation, and legislatively

\footnotetext{
${ }^{31}$ Ibid at para.4.6.

32 Ibid at para.4.7.

${ }^{33}$ Recommendation 4.1

34 Superannuation (Entitlements of Same-Sex Couples) Bill 1998 (Cth.). The member introducing the Bill (Mr. A.Albanese M.P.) gave the Second Reading Speech for the Bill on $7^{\text {th }}$ June, 1999. This means that the Bill will not lapse. Debate was adjourned until the Government allows it to be brought forward for further debate and a vote. The speech followed a report of the Australian Human Rights and Equal Opportunity Commission, Superannuation Entitlements of Same Sex Couples (June, 1999) was tabled in the Federal Parliament by the Attorney-General. The Commission found that present Australian superannuation law was in breach of two international conventions to which Australia is a party, the International Covenant on Civil and Political Rights and the I.L.O. Discrimination (Employment and Occupation) Convention.

${ }^{35}$ Sexuality Discrimination Bill 1995 (Cth.).
} 


\section{THE DENNING LAW JOURNAL}

encouraged moves, have come to recognise and protect the "employment packages" of persons governed by federal law. Nowadays, it is much more common to consider a person's total employment "package" rather than simply their base salary. Where there is a significant differentiation in superannuation and like employment benefits, unconnected with the quality of the employee's professional performance and concerned only with his or her private domestic arrangements, unjust discrimination can be seen in sharp relief. ${ }^{36}$ According to news reports, politicians of most political alignments in Australia have begun to appreciate the serious injustice which is worked by current superannuation and like laws in the case of persons living in stable same-sex relationships. ${ }^{37}$

Recently, an Australian Ambassador, presenting his credentials to the Monarch of the country to which he was accredited by Australia, took along his same-sex partner. Such relationships are legally recognised in that country where the action of the Ambassador would have been unremarkable. Yet in Australia the diplomat and his partner had to suffer the indignity of a tabloid headline reducing his serious professional career to the insult: "Three Queens in One Palace. "38 Tabloid media is one of the less enchanting aspects of the British heritage that we have succeeded to in Australia. It took more courage and honesty for the Ambassador to do as he did than to continue with pretence. It took more courage and integrity than the anonymous by-line writer exhibited in the newspaper concerned. And it must be acknowledged that the Australian Department of Foreign Affairs has, in this respect, observed a nondiscriminatory policy. The certified agreement between the Department and its officers under the Workplace Relations Act 1996 (Cth.) states:

36 See comment, D.McCarthy, "Superannuated" Brother-Sister (Melbourne), No. 182, (15 th $^{\text {th }}$ April, 1999) at p.7.

${ }^{37}$ C.Pearson, "Saving not such a super idea for same-sex couples" Australian Financial Review, (3 ${ }^{\text {rd }}$ May, 1999) at p. 19. Ms. Leane Burke M.P. for Prahran in the Victorian Parliament proposed a motion which was adopted by the Victorian State conference of the Liberal Party of Australia. It urged the Federal Government to "ensure same-sex partners are given equality of treatment with respect to superannuation payments as those given to opposite sex de facto partners." See J.McKenzie, "Super Boost for Equality Campaign" Brother-Sister (Melbourne), No. 182, (15 $5^{\text {th }}$ April, 1999) at p. 3.

38 Daily Telegraph (Syd.), $26^{\text {th }}$ February, 1999 at p. 7. 


\section{SAME-SEX RELATIONSHIPS}

"The conditions regarding the official recognition of de facto relationships for the purpose of the conditions of service applies regardless of sexual preferences." 39

Similar statutory "certified agreements" have been adopted by other federal departments and agencies in Australia. In practice, this means that for most benefits of office (but not yet superannuation) same-sex partnerships enjoy similar employment benefits in the federal service in Australia. Thus, in the Australian foreign service, the partners of officers are entitled to airfares to and from their posting; the payment of supplementary living allowances as a couple whilst overseas; the payment of other incidental allowances on the same basis where an entitlement arises (e.g. clothing allowances) and the payment of health cover by the Federal Government for both partners during the posting. It is necessary to have the relationship recognised by the relevant Department before the partners proceed to the posting. This is secured by the provision of a statutory declaration with accompanying evidence. But these and other benefits are then closely assimilated to those of any other non-married de facto partner. The achievement of such entitlements and practices evidences a commitment by those concerned in Australia to the principle of non-discrimination in the matter of sexuality within federal public employment.

The Parliament of Australia in respect of its own members, and in some areas of its own legislative responsibility, has begun to act. ${ }^{40}$ The Executive Government in Australia has also moved, in respect of its officers, to abolish discrimination in employment benefits and to exercise its powers under delegated legislation in a non-discriminatory way. Even the federal Judicature in Australia has begun to provide benefits of domestic and international travel for non-married partners of federal judges. But the Judges' Pensions Act 1968 (Cth.) remains resolutely unchanged.

\footnotetext{
39 Australia, Department of Foreign Affairs and Trade, Certified Agreement, 1998-2000

40 See Australia, Remuneration Tribunal, Determination No.2 of 1998, Members of the Parliament - Travelling Allowance, at para.2.8 ["A senator or member may nominate to the Special Minister of State one nominee as eligible to receive travel privileges under this entitlement, and, subject to any procedural rules made by the Special Minister of State, may vary that nomination from time to time"].
} 


\section{THE DENNING LAW JOURNAL}

\section{CONCLUSION}

On the other side of the world, in the United Kingdom, some of the subjects of this essay have been debated. The House of Lords in Parliament has twice proposed the removal of the discrimination that continues in the criminal law of England and Wales in relation to the age of consent for sexual activity. ${ }^{41}$ The attempts in England ${ }^{42}$ and Scotland ${ }^{43}$ to repeal the provisions of section 28 of the Local Government Act 1988 (U.K.) have run into opposition, much of it stemming from the churches. Foreign judges, including this author, who took part in a serious international conference on this topic held in London in 1999 are lampooned for drawing to notice the movement of law reform that is underway in many countries to redress the injustices and remove the discrimination of past laws affecting people because of their sexual orientation. I have myself been the target of such commentary. ${ }^{44}$ People, including lawyers, who in earlier times advanced the ideas of legal protection for the poor, for slaves, for destitute emigrants, for religious free-thinkers, for women, for the handicapped and for people of colour attracted, in their time, similar opprobrium. It must be borne with grace as the price of progress.

The law will usually accommodate itself to scientific explanations of reality. Community opinion also adapts, given time. Sadly, the churches and other spiritual leaders ${ }^{45}$ are often amongst the last to change their mind and to face reality. But Charles Darwin's explanations of evolution are no longer denounced by most church leaders. Save for a few peculiar jurisdictions, ${ }^{46}$ there

41 The consideration of the Sexual Offences (Amendment) Bill 1999 (U.K.) by the Lords was twice postponed in 1999 .

${ }^{42}$ Local Government Act 1988 (England \& Wales, separate legislation applies in Scotland) 5.28. A compromise was later struck with the Church of England. See Daily Telegraph $2^{\text {nd }}$ March, 2000 at p.6.

43 A campaign against reform was waged in Scotland by Cardinal Thomas Winning. See A.Kemp and A.Bell, "Scots fight to stay in closet" The Observer, $23^{\text {rd }}$ January, 2000 at p. 19. 44 M.Steyn, "The Rise of the FU Movement" The Spectator, $4^{\text {th }}$ March, 200022 at p.24 where the author was described as "the Peter Tatchell of the international legal set." 45 See "Chief Rabbi turns fire on section 28" The Times (London), $22^{\text {nd }}$ January, 2000 at p 1.

46 A recent opinion poll for the American Way Foundation found that over $83 \%$ of those polled favoured the teaching of evolution in U.S. schools. But according to the same poll most Americans do not favour teaching only evolution or creation. See report, Washington Post, $12^{\text {th }}$ March, 2000, at A12. 
are few attempts now by law to hide or deny scientific truth, although clearly inconsistent with a literal reading of the Biblical story of the Creation. So it has been in relation to interpretations of Scripture which suggested that black skinned people were flawed, ${ }^{47}$ that owning slaves represented the natural order of things and that women were the mere handmaidens of men. So it will be in relation to the current teachings of some religions that homosexuality is disordered and that homosexual acts, natural to people of that sexual orientation, are "intrinsically evil." 48

Once it became clear from scientific data that a small proportion of human beings in every society is homosexual, that they did not choose their sexual orientation and that (in the overwhelming majority of cases) they cannot change it, the attempt by the law to punish and stigmatise such people in their millions is revealed for what it is. It is intrinsically evil. It is as evil as the earlier laws, attitudes and beliefs which denigrated other human beings for indelible characteristics of their nature: their ethnicity, their skin colour and their gender.

Most judges and lawyers today understand these truths. Yet they are often bound to administer laws which have not caught up with the modern enlightenment. Gradually legislators are reforming those laws. It sometimes falls to practising lawyers and sitting judges to contribute to the process of reform.

To the end of his life, Lord Denning would probably have rejected the central thesis of this essay. But had he been alive and of this generation, he would, I believe, have been in the forefront of the understanding of the need for reform. It is an understanding which now goes far beyond those who are themselves of homosexual orientation. Everywhere the scales are dropping from our eyes. Injustice and irrational prejudice cannot long survive the scrutiny of just men and women. Silence is a formula that permits injustice and discrimination to remain. It is the light of truth that will expel error and demand reform. The common law as an instrument of justice now generally accepts this truth in the

\footnotetext{
47 The curse by Noah on Canaan was, according to some religious traditions, the origin of black skin and servitude, which for many in former times were synonymous. See Genesis, $9: 25$.

${ }^{48}$ The Congregation for the Doctrine of the Faith of the Roman Catholic Church in a Notification of $31^{\text {st }}$ May, 1999 reaffirmed the Church's teaching regarding the "intrinsic evil of homosexual acts," and ordered a priest and nun who had ministered to a homosexual congregation for twenty years to cease their ministry. See M.D.Kirby, supra n. 10.
} 


\section{THE DENNING LAW JOURNAL}

United Kingdom, Australia and like countries. Judges and lawyers play a part in the process. There is much need of legislative reform. In Australia, judicial and legislative changes have occurred. But much work remains to be done. 